\title{
Mao Zedong's Class Analysis Method and Its Contemporary Value Shuang $\mathrm{Li}^{*}$

\author{
No. 232, Wensan road, Xihu district, Hangzhou city, Zhejiang province
} 784826740@qq.com
}

\section{Keywords: Mao Zedong; Class analysis method; Contemporary value}

\begin{abstract}
In the article analysis of social classes in China written by Mao Zedong in 1925, the author combined the Marxist theory of class analysis with the concrete reality of Chinese society, and accurately divided the classes existing in Chinese society at that time, providing useful guidance for the formulation of revolutionary strategies. With the development of Chinese society becoming more and more complex and diversified, Mao Zedong's class analysis is still of great significance. Mao Zedong's thought of class analysis inspires us not to lose the Marxist theory of class analysis; In the new era, we should master the essence of class analysis theory and correctly analyze Chinese social class and class problems. The analysis of ideology should go deep into the class and stratum problems. We should use class analysis to build the Chinese dream of national rejuvenation.

Introduce. Since the reform and opening up, China has undergone profound adjustment and reform in its social and economic structure and industrial structure. China's social structure has become increasingly complicated and diversified, and some emerging strata have emerged. How can we properly analyze and grasp this new structure of Chinese society? At the same time, various ideological trends are surging in the ideological field, and people's values are diversified. How to view the hidden surge of various social trends and how to play the leading role of the mainstream Marxist ideology? How should we respond to the complexities of international and domestic forms in the context of "no debate" over class issues? These questions are important ideological and theoretical questions that must be considered and answered in contemporary China. I would like to reread the classic literature of Mao Zedong's analysis of the social classes in China, which can give us some valuable inspirations for our in-depth consideration of the above questions.
\end{abstract}

\section{Overview of Mao Zedong's Class Analysis Methods}

Through the in-depth interpretation of the analysis of various classes in Chinese society, Mao Zedong's class analysis method can be seen. Mao Zedong used the method of Marxist class analysis to make a relatively accurate division of Chinese social classes during the anti-imperialist and antifeudal revolution. We can study and grasp the formation background, purpose, method, important content and historical influence of Mao Zedong's class analysis method.

Historical Background of Formation of Mao Zedong's Class Analysis Method. Generally speaking, Mao Zedong's class analysis method was formed in the period of the national revolution. Specifically, it was influenced by the following aspects. First of all, from the perspective of the actual revolutionary situation, in 1925, when the anti-imperialist and anti-feudal revolution was surging, various classes in Chinese society showed different interest orientations, revolutionary attitudes and actions based on their own interests. How to correctly divide these classes, deal with the relations between the various classes in the revolution and formulate scientific and reasonable revolutionary strategies has become one of the important tasks that the communist party of China must consider and accomplish during this period. Secondly, from the point of view of KuomintangCommunist cooperation, the first cooperation started since 1924, but the old and new right within the Kuomintang made barriers, make the cooperation to revolution facing more or less difficulties, in order to be able to unite the Kuomintang , maintenance Kuomintang-Communist cooperation against imperialism and feudalism, the communist party of China must understand the China's social classes clearly from the thought and theory, adhere to the correct ideological line is especially 
important to strive for the victory of the revolution. Thirdly, there were two wrong ideological tendencies in the communist party of China at that time. One is the right opportunism represented by Chen Duxiu. The second is the "left" opportunism represented by Zhang Guotao. They all felt that their strength was inadequate, but, having neglected the peasant class, they were unable to find broad revolutionary allies. Finally, based on the above circumstances, Mao Zedong summarized the experience and lessons of Chinese revolution in history. He pointed out that "all the revolutionary struggles in China in the past have achieved little results, and the basic reason is that they cannot unite real friends to attack real enemies." Therefore, it is very important and necessary to make a distinction between the friends and enemies of the revolution. Mao Zedong's class analysis method was born in this situation.

The Purpose of Mao Zedong's Class Analysis Method. "Who are our enemies? Who are our friends? This issue is at the forefront of the revolution." He stressed that the basic reason why all the revolutions in China in the past were less effective was that we could not unite with real friends to attack real enemies. Therefore, in the period of the great revolution, the struggle against imperialism and feudalism under the cooperation of the Kuomintang and the communist party, if we want to achieve achievements, we have to draw lessons from history, distinguish between the enemies and friends of the revolution, and formulate correct revolutionary strategies. Therefore, the direct aim of Mao Zedong's class analysis method is to formulate revolutionary strategies. And the revolutionary strategy ultimately serves the revolutionary struggle, precisely for class struggle, just as "the analysis of the classes in Chinese society" is not class struggle, but class analysis. But Mao Zedong engaged in class analysis for the sake of class struggle." It can be seen that the ultimate purpose of Mao Zedong's class analysis method is to carry out class struggle and to participate in the concrete practice of Chinese revolution.

Class Analysis Standards in the Methods of Mao Zedong's Class Analysis Method. Throughout the different classes in Chinese society analysis we can see that Mao Zedong in classifying Chinese society each class to the economic standard and the standard of the unity of political attitude, by Mao Zedong pointed out "we are going to see friends and enemies, a case will be different classes in Chinese society economic position and attitude for revolution, make a general analysis". However, this is not to say that the economic standard and the political attitude standard play an equal role in the analysis. Mao Zedong's class analysis method is loyal to the Marxist class analysis theory. "The Marxist method of class analysis emphasizes the ownership of the means of production and the way of distribution as an important basis for classifying classes and classes." Mao Zedong embodies the class analysis method to the economic standard as the fundamental basis a hierarchy, from his will in context, can be seen in the classification of China's social classes, the landlord class and the comprador class, the national bourgeoisie, the petty bourgeoisie, half of the proletariat, the proletariat is the five classes reflected their position in the economic structure is different, different income and a different reality situation. Their respective attitudes towards the revolution are determined by their economic status.

The Division of Chinese Social Classes by Mao Zedong Through Class Analysis. In the analysis of Chinese social classes, Mao Zedong divided the social class into five classes: landlord class and comprador class, national bourgeoisie, petty bourgeoisie, semi-proletariat and proletariat. At the same time, there are a large number of nomadic proletarians. At the end of the article, he objectively summarized the position and attitude of these big classes in the revolution. The enemies of the revolution were "all the warlords, bureaucrats, compradors, the great landlords and a portion of the reactionary intelligentsia that colluded with imperialism"; the friends of the revolution were "all the semi-proletariat, the petty bourgeoisie"; the leading force of the revolution was the industrial proletariat. The situation of the national bourgeoisie is more special. Their right wing may be the enemy of the revolution, and their left wing may be the friend of the revolution. This shows clearly the class condition of Chinese social revolution and illustrates the problem of friend and foe in the revolution.

The Historical Significance of Mao Zedong's Class Analysis Method. The method of class analysis in Mao Zedong's analysis of the different classes of Chinese society made an important 
contribution to recognizing the enemies and friends of the revolution. The historical significance of Mao Zedong's class analysis method is reflected in several aspects. First, Mao Zedong used class analysis method to reasonably analyze all classes of Chinese society, and found the reliable leading force of the industrial proletariat and the vast ally of the peasant class. Mao Zedong deeply knew that the most profound and greatest strength of the Chinese revolution lies in the people. Only by uniting all forces that can be united can we strengthen the revolutionary ranks and effectively attack the real enemies. Second, Mao Zedong pointed out the dual character of the national bourgeoisie. They have relatively contradictory attitudes towards the revolution, and in the face of different struggle situations, they will show or need the revolution or doubt the attitude of the revolution. This provided the scientific basis for the Chinese communist party to formulate the policy to the national bourgeoisie later. Third, Mao Zedong creatively applied the Marxist theory of class analysis to Chinese society and formed the class analysis method, which provided us with useful guidance for class analysis. At the same time, as the beginning of the formation of the theory of new democracy, the analysis of class provides useful guidance for the formulation of the general line of the new democratic revolution, the anti-imperialist and anti-feudal revolution of the masses under the leadership of the communist party of China.

\section{The Contemporary Value of Mao Zedong's Class Analysis Method}

From the above analysis of Mao Zedong's class analysis method, we can see that the correct application of Mao Zedong's class analysis method has provided favorable help for obtaining broad power and determining the correct route in the revolutionary period. So in today's peace and development become the theme of The Times, the international competition and cooperation, adhere to the socialist road with Chinese characteristics in China, efforts to achieve the great rejuvenation of the Chinese nation the Chinese dream of the moment, the specific content of Mao Zedong's class analysis method is not adapt to the reality of China's social development, but we should be on the basis of inheriting the essence of innovation and development, with the scientific analysis methods of analysis and observation of the modern Chinese society.

Inheriting the Essence of Mao Zedong's Class Analysis Method, Correctly Analyze and View the problems of Each Class and Stratum in Chinese Society. Looking back on Mao Zedong's class analysis method, the purpose is to grasp the essence of it and grasp the profound meaning behind it. Inheriting the essence of Mao Zedong's class analysis method is reflected in the fact that Chinese society should adhere to the correct purpose of class and class analysis. After more than 30 years of reform and opening-up, China has gradually established a socialist market economy system, and with the adjustment of economic structure and industrial structure, China's social structure has also undergone significant changes. The emergence of new social classes, such as the emergence of individual workers and private business owners, the emergence of a special group of migrant workers, and the emergence of entrepreneurs, technicians and managers in hightech and emerging industries, has complicated the social class in China. At the same time, we must not neglect that under the "one country, two systems" system, Hong Kong, Macao and Taiwan are under the capitalist system, which means that China exists and will exist for a long time. The emergence of these complex class and class conditions in our country further proves the importance of class and class analysis. Today, the essence of the Mao Zedong class method is not to engage in class struggle, but to make a correct analysis of all classes and strata of Chinese society, unite all patriotic forces supporting socialist construction to carry out socialist construction, coordinate the relations between all classes and strata, and integrate the interests of all classes and strata.

Inheriting the essence of Mao Zedong's class analysis method is also embodied in that we should innovate and develop the class analysis method. We say that the Mao Zedong follows a standard of division that combines economic analysis with political attitude analysis, in which economic status dominates. Historical materialism tells us that social existence determines social consciousness. People's political attitudes ultimately depend on their economic status in social production. Economic standard is the division standard that we must insist when carrying out class, stratum analysis. In addition, we should also grasp the political standard of class and stratum division. 
Party's 16 big reports pointed out that "cannot be simply put any property or how much property as we judge people are politically advanced and backward standard, the main should look at the performance of their ideological and political situation and the reality, to see how their property is gained, and how to control and use of property, to see them with their own labor to build the contributions to the socialist cause with Chinese characteristics." 2001 research report of Chinese academy of social sciences on the social stratum of contemporary China, classifying Chinese society into ten strata from the perspective of occupational classification. "Since the reform and opening up, China's productive forces have been advancing by leaps and bounds, and its social structure has undergone profound changes". The inspiration is that we should be able to scientific methods of class analysis and stratum analysis applied to connect, to adapt to the needs of the transformation of the social situation, find a reasonable division of the standard, so as to correct analysis of China's social classes and class problems.

Marxist Theory of Class Struggle and the Method of Class Analysis Should not be Lost. Deng Xiaoping given a speech in 1979 which title is "adhere to the four cardinal principles" ,he stressed that "we must see, in a socialist society, there are still counter-revolutionaries, enemy agents, the criminal analysis of all kinds who undermine socialist order and other bad elements, there are new exploitation, embezzlement, speculation, and can't completely eliminate the phenomenon in a long period of time. The struggle against them is different from the struggle against the class in the past history (it is impossible for them to form an open and integral class), but it is still a special form of class struggle, or the legacy of the special form of class struggle in the context of socialism." some of the phenomena he mentioned are still present today, so the struggle against these enemies cannot be taken lightly.

Wang Weiguang, a professor at the Chinese academy of social sciences, pointed out that "class struggle in the international field is not extinguishable, so is class struggle in domestic." This sobering voice reminds us, in the face of complex domestic and international environment, must have a strategic vision and the sense of anxiety, since the class struggle still exists, so we must adhere to the class analysis method in some areas. Mao Zedong's class analysis method adheres to the Marxist class analysis method and makes important theoretical contributions to the Chinese revolution. This reveals us that the scientific nature of Marxist class struggle and class analysis method proves that as long as there are conditions for class struggle and class differences have not been eliminated, the class struggle theory and class analysis method must be adhered to. Marxist thought, in the highly developed productivity, material wealth, extremely rich in communist society, to eliminate the cause for class and class differences exist, so the growth of the productive forces in the primary stage of socialism in our country has not establish the elimination of class and class difference under the condition of material basis, that is to say, class and class differences still exist in the realistic society, we must adhere to class analysis method for the analysis of China's social class problem. In addition, the realistic domestic and international environment also reminds us that the western capitalist countries led by the United States have been trying to "divide" and "westernize" China at the international level, and that the two forces of capitalism and socialism still exist in the world. At home, there is the "Taiwan independence" and "Tibet independence" "Xinjiang independence" secessionist forces, there are all sorts of bad behavior and criminal behavior destroying the socialist construction, there is also a part of the corrupt officials, for the reality we are not losing the method of class analysis, only tell which is blocking the forces of the construction of socialism with Chinese characteristics, can we crack down on all kinds of illegal crime and domestic boycott foreign anti-china forces, to create a stable and harmonious political situation and social atmosphere.

The Analysis of Ideological Issues Should Go Deep into the Question of Class and Stratum. When Mao Zedong used class analysis method to analyze Chinese social classes, he followed the social and economic status, income status and realistic experience of each class to start dividing classes, and also paid attention to grasping the attitudes of each class to the revolution. For example, he believed that the landlord class and the comprador class represented the most backward and reactionary productive relations in China and hindered the development of China's productive 
forces. Therefore, their political attitudes were always on the side of imperialism and extreme counter-revolutionaries. And not to take any means of production, the proletariat can only sell labor to maintain life, its low economic status, suffered cruel treatment, so they are most rebellious, the most progressive class in modern China. This shows that people in different class, class status, their political attitudes will follow. Historical materialism thinks that social being determines social consciousness, this enlightens us in order to analyze the problem of social ideology, we should go deep into the class and stratum problem and find the key to the problem.

Nowadays, Chinese society is a more open and diversified society, and the interest relationship is complicated and the value choice is diversified development trend. How to effectively coordinate the complex interest relationship and lead the multi-value choice has become an important issue before us. In particular, under the atmosphere of "a hundred flowers bloom and a hundred schools of thought contend", various social trends flow, if not analyzed and correctly guided, will inevitably have a negative impact on the mainstream ideological construction. "The current scope of class struggle highlights the ideological sphere." We should correctly analyze the economic factors behind various social trends of thought, see that different schools of consciousness represent the voices of different classes and strata in the society, go deep into the inner class to grasp various demands, and reasonably guide various trends of thought, and actively occupy ideological and theoretical positions with Marxism.

Applying the Marxist Class Analysis Method Correctly to Jointly Build the Chinese Dream of the Great Rejuvenation of the Chinese Nation. In the course of adhering to the path of socialism with Chinese characteristics, it is not empty talk to stick to the theoretical guidance of Marxism and Mao Zedong thought. We should inherit the essence of the class analysis method of Mao Zedong and correctly apply the Marxist class analysis method to analyze the class and class problems facing Chinese society. Especially, with the increasingly prominent contradiction of social interests, it challenges the communist party of China to balance class relations and coordinate class interests. To truly grasp the essence of the Marxist class analysis method is the important guidance for the party to formulate the correct policy, line and policy at the present stage. Only by correctly applying Marxist class analysis can we constantly strengthen the party's class foundation, expand the party's mass foundation, consolidate the party's ruling foundation, effectively integrate the forces of all social classes and grassroots, build a harmonious socialist society, and contribute to the realization of the Chinese dream of the great rejuvenation of the Chinese nation.

\section{References}

[1] Mao Zedong anthology (volume I) [M]. Beijing: people's publishing house, 1991, page 4.

[2] Xiao Shimei ,Jiang Xianming. On class analysis method of MAO zedong -- the first step of marxism's localization in China [J] Dong yue tribune 2012 (08).

[3] Chen Yue, Xiong Jie, He Lingling. Research report on the theory and reality of Marxism class analysis method [J]. Marxism research, 2011 (09).

[4] Selected and compiled important documents since the 16th national congress of CPC [M]. Beijing: central literature publishing house, 2005, page 12.

[5] Selected and compiled important documents since the third plenary session [M]. Beijing: people's publishing house, 1982, page 92.

[6] Wang Weiguang. Upholding the people's democratic dictatorship is not an unreasonable [J]. Red flag manuscript, 2014 (10).

[7] Liu Baoguo. Contemporary significance of class view and class analysis methods [J]. Marxism research, 2009 (08). 